\title{
Economic Efficiency of Milk Procurement in Sirsa Cooperative Milk Plant (Haryana)
}

\author{
Ripi Doni" and A.K. Chauhan \\ Department Economics, National Dairy Research Institute, Karnal, Haryana, India \\ *Corresponding author: ripidoni14@gmail.com
}

\begin{abstract}
The present study was conducted at a cooperative milk plant having the capacity of 1.1 lakh Litre Per Day (LPD). The investigation was carried out to study the cost of procurement and economic efficiency in the cooperative milk plant Sirsa (Haryana). The study shows that procurement cost was ₹ 1.83 per litre of milk. Among all the cost constituent in procurement process transportation cost had the highest share (43.72 per cent) followed by collection cost (26 per cent), chilling cost (21.86 percent) and reception cost (8.20 per cent).
\end{abstract}

Keywords: Cooperative milk plant, economic efficiency, procurement

India remains unsurpassed in terms of milk production but still has a long way to go in the field of dairy industry. There has been a decent progress in the field of business in dairying since the adoption of cooperative system in 1965. India being the initiator of cooperative system, it should be a role model in the area. The success of dairy industry is immensely detemined by the procurement activities such as collection, transportation, chilling and reception. As milk procurement is the key step in dairy industry, the sustainability of dairy plant is largely influenced by it. In India cooperative system consisting of 3 tier is the most widely practiced one and it is growing widely since its incepton. Most of the dairy activity is largely based upon a three tier system under which, the primary village cooperative societies at the grassroot level are linked with district union and state federation $n$ the topmost structure of pyramid which are guided by the national co- operative dairy federation in India. With the liberalization and privatization, cooperative dairy plants are exposed to global market and players such as private dairy plants, milk vendors, contractors and other agencies dealing with milk procurement. Present study is an attempt to understand the cost incurred in cooperative milk procurement system and a breakdown of cost component for detailed understanding of cost factors.

Researchers such as Sharma et al. (1974), Rao (1976), Sandhu (1980), Rawat and Singh (1984), Chauhan (1987), Pundir (1988), Malik (1989), and Rangasamy (2007) studied the cost of collection of milk, cost of transportation and chilling of milk in North western and southern India.

\section{Data Sources and Methodology}

Haryana state was purposively selected for the investigation. The number of Cooperative Milk Plants registered under Milk and Milk Product Order (MMPO) is 6 with total registered capacity of 6.45 (LLPD) as on November-2015 (HDDCF). Milk production in the state has increased from 60 lakh tonne in 2010 to 74.41 lakh tonne in 2014 which means in 5 year the milk production has increased by almost 15 lakh tonne. Per capita per day availability of milk has increased from 662 grams/day in 2010 to 800 grams in 2014 which is the $2^{\text {nd }}$ highest. Therefore, the tremendous progress in dairy development provided the suitable background to conduct this study in Haryana. 
Out of the 6 dairy Plants under Haryana Dairy Development Cooperative Federation Limited, Sirsa Plant having the widest variety of product mix and the $2^{\text {nd }}$ latest Plant among all the Plant was selected for the study. The wider Product mix, maintenance of detailed data and records and easy accessibility to data prompted for selection of the Plant. The required data for the financial year 2014-15 for procurement were collected from each selected village cooperative societies and chilling centre associated with the milk plant.

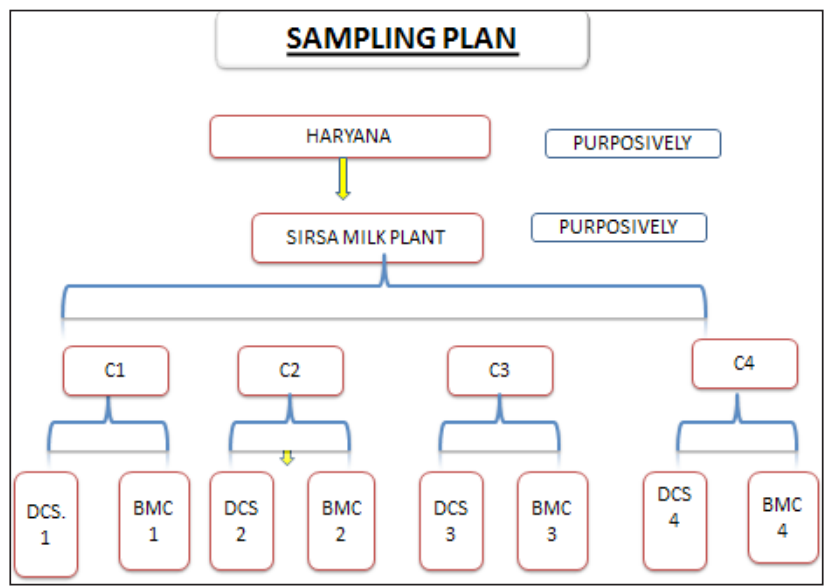

Fig. 1: Sample Plan for Estimating the Procurement Cost

DCS: Dairy Cooperative Society with no BMC; BMC: DCS with Bulk Milk Cooler; C1, C2, C3, C4: Chilling Centres.

Cost of Milk Procurement: The procurement cost constitute of collection cost, transportation cost, chilling cost and milk reception cost.

(i) Chilling Cost: The four chilling centre associated with the plant was selected for the purpose of estimating the chilling cost. Chilling cost in each chilling centre,

Cost of chilling per litre $=$

$$
\frac{\text { Total chilling cost }}{\text { Total quantity of milk chilled }}
$$

(ii) Cost of Collection: From each chilling centre the most active cooperative society as recommended by the procurement incharge was selected for the purpose of calculating the collection cost. Collection cost is the cost incurred at the dairy cooperative society level for collection of milk from the cooperative member at village level. Cost incurred to carry out the activities for the purpose of milk collection for four different dairy cooperative societies were estimated and the average cost of the selected society was estimated.

Cost of collection per litre $=$

$$
\frac{\text { Total cost of collection }}{\text { Total milk collected per annum }}
$$

(iii) Cost of Transportation: Milk was transported from two different routes. Direct transportation from the Dairy Cooperative Society to the plant which owned BMC (Bulk Milk Cooler). In case of society which does not own BMC, milk was first transported from collection centre to chilling centre which was than transported to the milk plant. Therefore from each chilling centre one Cooperative Society with BMC and one without BMC were selected. The cost of these two routes was separately worked out and average cost of transportation was worked out.

Transportation cost per litre $=$

$$
\frac{\text { Total cost of transportation in two routes }}{\text { Total quantity of milk trnasported }}
$$

(iv) Reception Cost: Milk is received at the reception dock of the plant. Cost of reception includes fixed cost and variable cost incurred in the reception.

Cost of procurement per litre $=$

$$
\frac{\text { Total procurement cost }}{\text { Total quantity of milk procured }}
$$

\section{RESULTS AND DISCUSSION}

Procurement cost worked out have been presented in the following section.

\section{Cost of Collection of Milk}

Average cost of collection per litre of milk has been estimated component wise for the four dairy co-operative societies selected for the study. Table 1 indicates that average cost of collection per litre of milk as ₹ 0.48 per litre. The average quantity of milk collected per society was 3,92,375.00 liters per annum. The share of fixed cost was 46.40 per cent and share of variable cost in the total cost was found to be 53.60 per cent. Fixed cost includes the depreciation on fixed assets such as cans, Bulk Milk Cooler, electric generators, Data Processor based Automatic Milk Collection Unit (DPAMCU) 
Table 1: Cost Component of Collection of Milk

\begin{tabular}{lcc}
\hline Components of cost & Average Collection Cost ₹/Annum) & Cost \% \\
\hline 1. Variable cost & & 35.90 \\
\hline Wages and salaries & 68250 & 8.21 \\
Repair and maintenance & 15600 & 7.42 \\
Electricity & 14100 & 1.31 \\
Stationeries & 2490 & 0.45 \\
Detergent & 853 & 0.31 \\
Miscellaneous & 595 & 53.60 \\
Sub Total & 101888 & 29.33 \\
2. Fixed cost & & 9.97 \\
\hline Depreciation & 55755 & 7.10 \\
Interest & 18944 & 46.40 \\
Rent & 13500 & 100.00 \\
Sub total & 88199 & \\
Total (1+2) & 190086 & \\
Total milk collected per annum (litres) & 392375 & \\
Cost of collection per litre of milk (₹ Per litre) & 0.48 & \\
\hline
\end{tabular}

etc and the cost of the rent. The component wise cost analysis revealed that wages and salaries accounted for 35.90 per cent which was highest among all component followed by depreciation on assets (29.33 per cent), interest (9.97 per cent), repair and maintenance (8.20 per cent), electricity (7.42 percent), rent (7.10 per cent), stationeries (1.31 per cent), detergent ( 0.45 per cent), and miscellaneous (0.31 per cent).

\section{Transportation Cost}

Total transportation cost of milk is determined by the amount of milk transported, distance travelled by the milk, salary and wages human labour. The cost of transportation was worked out for three different routes, viz., (i) from collection centre to dairy plant; (ii) from collection centre to chilling centre; and (iii) from chilling centre to dairy plant.

Table 2 reflects the cost of transportation. Transportation cost in direct route was observed to be highest which was Rs 1.08 per litre because of more distance covered and less quantity transported indicating that transportation cost is directly related to distance and indirectly varies with quantity. Overall average transportation cost was observed to be ₹ 0.78 per litre. The calculations reveals that fixed cost share 7.71 per cent and variable cost constitute 92.29 per cent of total cost.

\section{Cost of Milk Chilling}

Chilling cost per litre of milk was calculated for three different chilling centres located at different places namely $\mathrm{C} 1, \mathrm{C} 2$, and $\mathrm{C} 3$, which were owned by the co-operative milk plant. Chilling plant C4 was on hired basis which was charged at fixed rate on slab basis. The average chilling cost per litre of milk was found to be ₹ 0.36 per litre, ₹ 0.43 per litre, $₹ 0.52$ per litre, and $₹ 0.28$ per litre for $\mathrm{C} 1, \mathrm{C} 2, \mathrm{C} 3$ and $\mathrm{C} 4$ chilling centres respectively. The average chilling cost for the four chilling centre together was found to be ₹ 0.40 per litre. Largest cost was on labour component (66.00 per cent).

\section{Cost of Milk Reception}

The cost of receiving the milk at the dock of the selected cooperative milk plant has been calculated and is presented in Table 4 . The overall reception cost was observed to be ₹ 0.15 per litre. The share of fixed cost was around 9.31 per cent and variable cost in the total cost was found to be 90.69 per cent.

Table 5 shows that the cost of procurement in the milk plant and milk-shed. Procurement cost was worked out to be ₹ 1.83 per litre of milk. The table shows that transportation cost has the bulk share which is around 44.00 per cent of total cost followed by collection cost (26.23 per cent) and reception cost (8.20 per cent). 
Table 2: Cost of Transportation (2014-15)

\begin{tabular}{|c|c|c|c|c|c|c|}
\hline $\begin{array}{l}\text { Component of cost } \\
\text { (1) }\end{array}$ & $\begin{array}{l}\text { From collection } \\
\text { center to milk } \\
\text { plant directly } \\
\text { (2) }\end{array}$ & $\begin{array}{l}\text { From collection } \\
\text { center to chilling } \\
\text { center } \\
\text { (3) }\end{array}$ & $\begin{array}{l}\text { From chilling } \\
\text { center to milk } \\
\text { plant } \\
\text { (4) }\end{array}$ & $\begin{array}{l}\text { Collection centre } \\
\text { to chilling centre + } \\
\text { chilling centre to } \\
\text { plant } \\
\text { (5) }\end{array}$ & $\begin{array}{l}\text { Average cost of } \\
\text { transportation for } \\
\text { all the four routes } \\
\text { (6) }\end{array}$ & $\begin{array}{c}\text { Cost } \\
\%\end{array}$ \\
\hline \multicolumn{7}{|c|}{ 1. Variable Cost (000' ₹/annum) } \\
\hline Diesel & 365.00 & 200.75 & 471.46 & 672.21 & 628.62 & 47.89 \\
\hline $\begin{array}{l}\text { Repair and maintainance } \\
\text { of owned milk tanker }\end{array}$ & 75.34 & 38.95 & 461.97 & 500.92 & 444.84 & 33.89 \\
\hline Hiring of vehicle & 8.40 & 4.34 & 51.48 & 55.82 & 49.57 & 3.78 \\
\hline General expenses & 0.90 & 0.47 & 5.52 & 5.99 & 5.32 & 0.41 \\
\hline Sub total & 494.95 & 55.83 & 1268.31 & 1324.14 & 1211.39 & 92.29 \\
\hline \multicolumn{7}{|l|}{ 2. Fixed Cost (000' ₹/Annum) } \\
\hline Depreciation & 3.72 & 7.70 & 91.33 & 99.03 & 86.60 & 6.60 \\
\hline Interest & 2.47 & 1.28 & 15.16 & 16.44 & 14.60 & 1.11 \\
\hline Sub total & 5.67 & 8.98 & 106.49 & 115.47 & 101.20 & 7.71 \\
\hline Total cost & 501.14 & 64.81 & 1374.79 & 1439.60 & 1312.59 & 100.00 \\
\hline $\begin{array}{l}\text { Average milk transported } \\
\text { (litre/annum) }\end{array}$ & 465.38 & 228.13 & 2965.63 & 3193.75 & 2834.41 & \\
\hline $\begin{array}{l}\text { Transportation cost per } \\
\text { litre (₹) }\end{array}$ & 1.08 & 0.28 & 0.46 & 0.75 & 0.78 & \\
\hline
\end{tabular}

Table 3: Cost of Chilling

\begin{tabular}{lcccccc}
\hline \multicolumn{1}{c}{ Component of cost } & $\begin{array}{c}\text { C1 } \\
\text { Goriwala }\end{array}$ & $\begin{array}{c}\text { C2 } \\
\text { Jiwannagar }\end{array}$ & $\begin{array}{c}\text { C3 } \\
\text { Patlidabur }\end{array}$ & $\begin{array}{c}\text { C4 } \\
\text { Gosiana }\end{array}$ & $\begin{array}{c}\text { Av. annual } \\
\text { chilling cost }\end{array}$ & $\begin{array}{c}\text { Cost } \\
\text { \% }\end{array}$ \\
\hline 1. Variable Cost (000' ₹/annum) & & & & & & \\
\hline Wages and salaries & 1020.00 & 660.00 & 660.00 & 600.00 & 66.26 \\
Consumables & 19.00 & 18.00 & 18.00 & 13.14 & 1.45 \\
Stationeries & 3.00 & 1.00 & 0.90 & 1.43 & 0.16 \\
Electricity and diesel & 2.00 & 1.00 & 1.00 & 1.261 & 0.14 \\
Repair and maintenance & 30.00 & 10.00 & 10.00 & 14.46 & 1.60 \\
Sub Total & $\mathbf{1 0 7 4 . 0 0}$ & $\mathbf{6 9 0 . 0 0}$ & $\mathbf{6 9 0 . 0 0}$ & $\mathbf{6 3 0 . 2 9}$ & $\mathbf{6 9 . 6 1}$ \\
\hline 2. Fixed Cost (000' ₹/annum) & & & & & 94.69 & 10.46 \\
Depreciation & 139.46 & 138.45 & 114.70 & 93.71 & 10.35 \\
Interest & 190.45 & 58.79 & 81.52 & & 86.76 & 9.58 \\
Rent & 180.00 & 60.000 & 60.00 & & $\mathbf{8 7 5 . 1 8}$ & $\mathbf{9 6 . 6 5}$ \\
Sub total & $\mathbf{5 0 9 . 9 1}$ & $\mathbf{2 5 7 . 2 4}$ & $\mathbf{2 5 6 . 2 2}$ & & $\mathbf{9 0 5 . 4 8}$ & $\mathbf{1 0 0}$ \\
Total cost (1+2) & $\mathbf{1 5 8 4 . 3 1}$ & $\mathbf{9 4 7 . 5 4}$ & $\mathbf{9 4 6 . 2 2}$ & & 3315.88 & \\
Average milk chilled/annum & 4380.00 & 2190.00 & 182.50 & 3467.50 & 0.40 & \\
Cost per liter & 0.36 & 0.43 & 0.52 & 0.28 & & \\
\hline
\end{tabular}

C1, C2, C3, C4 refers to Chilling Plants.

Table 4: Cost of Milk Reception

\begin{tabular}{lcc}
\hline \multicolumn{1}{c}{ Components of cost } & Total cost (000' ₹/annum) & Cost $\%$ \\
\hline 1. Variable cost & & \\
\hline Wages and salaries & 1056.00 & 73.06 \\
Cost of electricity & 157.16 & 10.87 \\
Cost of water consumed & 64.65 & 4.47 \\
Sampling set & 18.00 & 1.25 \\
Repair and maintenance & 10.00 & 0.69 \\
Stationary cost & 5.00 & 0.35 \\
Sub total & $\mathbf{1 3 1 0}$ & $\mathbf{9 0 . 6 9}$ \\
\hline
\end{tabular}




\begin{tabular}{lcc}
\hline 2. Fixed cost & & \\
\hline Interest & 74.76 & 5.17 \\
Depreciation & 59.87 & 4.14 \\
Sub total & $\mathbf{1 3 4 . 6 3}$ & $\mathbf{9 . 3 1}$ \\
Total cost (1+2) & $\mathbf{1 4 4 5 . 4 4}$ & $\mathbf{1 0 0 . 0 0}$ \\
Total milk received (litre) & 9609.62 & \\
Reception cost per litre (₹) & 0.15 & \\
\hline
\end{tabular}

Table 5: Total Cost of Procurement (₹/litre)

\begin{tabular}{cccccc}
\hline Component of cost & $\begin{array}{c}\text { Collection Cost } \\
(\mathbf{1})\end{array}$ & $\begin{array}{c}\text { Chilling cost } \\
\mathbf{( 2 )}\end{array}$ & $\begin{array}{c}\text { Transportation cost } \\
\mathbf{( 3 )}\end{array}$ & $\begin{array}{c}\text { Reception cost } \\
\mathbf{( 4 )}\end{array}$ & $\begin{array}{c}\text { Procurement cost } \\
(\mathbf{1}+\mathbf{2}+3+\mathbf{4})\end{array}$ \\
\hline Cost per litre & 0.48 & 0.40 & 0.80 & 0.15 & 1.83 \\
Cost $\%$ & 26.23 & $\mathbf{2 1 . 8 6}$ & $\mathbf{4 3 . 7 2}$ & $\mathbf{8 . 2 0}$ & $\mathbf{1 0 0}$ \\
\hline
\end{tabular}

\section{CONCLUSION}

Milk and milk products provide a critical source of nutrition and are a source of living to millions of people. Dairy processing is the fast growing business but bounded by inefficiency in procurement and processing. High cost of transportation has always been a problem in India due to unfavorable road condition while in case of processing, high energy cost is a serious problem. To survive in this cut throat competition, Indian Dairy Industry has to be efficient and effective. Even though dairy plants are a vital institutions in the marketing channel but they undergo tremendous pressure while fulfilling the conflicting agenda's of producers and the ultimate consumers. Farmers want to increase their share per litre of milk and consumer want maximum satisfaction per litre of milk. To balance these contrasting goals dairy plant should be innovative with proper management strategy. If the target is of potential cost savings in each of the components, transportation cost would invariably emerge at the top. The analysis of data on procurement revealed that Procurement cost found to be ₹ 1.83 per litre during the study period. The share of transportation cost was highest in procurement cost accounting for 43.72 per cent of the total cost followed by collection cost (26.23 per cent), chilling cost (21.86 per cent), and reception cost (8.20 per cent).

On the basis of discussion with the farmers and the detailed study carried out various suggestions are listed below which can enhance the milk procurement system:

(i) Regular payment to the milk collection centre so that the farmer does not sale the milk to the private milk plants. (ii) Providing various intiantives such as feed, medicines and other instrument such as bucket to the cooperative member in subsidized rate so as to encourage more active participation.

(iii) Training and awareness creation on sanitation and maintainence of the animal sheds, nutrition to animal, scientific milking etc.

\section{REFERENCES}

Chauhan, A. 1987. Economic Analysis of Different Milk Procurement Systems in a Private Sector Dairy Plant in Western Uttar Pradesh (Doctoral dissertation, NDRI).

Khokhar, A.K. 1985. Economics of Milk Procurement for Feeder Balancing Dairy, Partapur, Meerut (UP) (Doctoral dissertation, NDRI).

Malik, M. 1989. Economic evaluation of organised milk procurement by Haryana dairy development cooperative federation (Doctoral dissertation, NDRI, Karnal).

Ram, K. \& Kulwant, S. 1987. Cost of collection of milk in a public sector plant. Asian J. Dairy Res, 6: 130-134.

Rangasamy, N. 2001. Economics of Milk Procurement in a Cooperative Dairy Plant in Tamil Nadu (Doctoral dissertation, NDRI).

Rangasamy, N. \& Dhaka, J.P. 2007. Constraints faced by Co-operative and private dairy plants in Tamil Nadu: A comparative analysis. Indian Journal of Dairy Science, 60(4): 300-306.

Rangasamy, N. \& Dhaka, J.P. 2007. Milk Procurement Cost for Co-operative and Private Dairy Plants in Tamil Nadu-A Comparison. Indian Journal of Agricultural Economics, 62(4): 679.

Sarker, D. \& Ghosh, B.K. 2008. Economics of milk production in West Bengal: Evidence from cooperative and noncooperative farms. East West Journal of Economics and Business, 11(1\&2): 132-152.

Sharma, K.N.S., Chander, J. \& Singh, S. 1974. Study on the procurement of milk by organized sector of dairy industry in India. Indian Dairyman, 26(3): 107. 
